\title{
Globalization and Developing Economy: Evidence from Nigeria
}

\author{
Cosmas Ogobuchi Odo ${ }^{*}$, Ishmael Agbo², Benjamin Agbaji ${ }^{2}$ \\ ${ }^{1}$ Department of Marketing, Enugu State University of Science and Technology, Enugu, Nigeria \\ ${ }^{2}$ Department of Insurance and Risk Management, Enugu State University of Science \& Technology, Enugu, Nigeria \\ Email: ^cosmasudoka@yahoo.com,Agbo.ishmael@yahoo.com, agbajiben@gmail.com
}

How to cite this paper: Odo, C. O., Agbo, I., \& Agbaji, B. (2020). Globalization and Developing Economy: Evidence from Nigeria. Journal of Financial Risk Management, 9, 518-530.

https://doi.org/10.4236/jfrm.2020.94028

Received: October 28, 2020

Accepted: December 28, 2020

Published: December 31, 2020

Copyright ( 2020 by author(s) and Scientific Research Publishing Inc. This work is licensed under the Creative Commons Attribution International License (CC BY 4.0).

http://creativecommons.org/licenses/by/4.0/

(c) (i) Open Access

\begin{abstract}
The paper essentially interrogates the question as to whether globalization has promoted economic growth in Nigeria in line with the ambitious expectations of the promoters of the concept especially, the World Bank and the International Monetary Fund. The article both clarifies and demystifies the recentness of the phenomenon usually foisted on the mind, by beaming a search light through its evolutionary path. Evidences from literature were examined for a clue for a support of economic growth hypothesis in the particular instance of a local economy, Nigeria. It was found that whereas globalization may have improved the economies of advanced democracies, the domestic economy received marginal benefits but in the main was undermined owing to a host of factors including, weak technical base, unhealthy macro-economic environment and poorly diversified economic base. This has rendered her a net loser in the competitive struggle engendered by globalization. The paper recommends economic policy strategies that not only diversify her economic investments but allow her to selectively engage the world in a way that protects the investments of locals from undue competition from unregulated globalization.
\end{abstract}

\section{Keywords \\ Competition, Diversification, Globalization, Global Consciousness \\ Unemployment}

\section{Introduction}

Globalization remains a subject of intense research and much heated debate among academics and economic development experts. Proponents of globalization posit that the phenomenon promotes growth of global economy given the 
right mix of macroeconomic and technical policy environments (Lawal, 1982: pp. 247-248; Ianchovichina \& Martin, 2004; Obadan, 1993; Williamson, 1997). Normally, reform of major sectors of an economy becomes the minimum template that grants globalization a free rein. Research findings that show a strong correlation between globalization and economic growth are often presented as proof of the virtue of globalization. They are further used as basis for urging developing countries to embrace economic reform. But when some of the research findings in support of globalization seem to contradict local economic realities, policy makers should be cautious in regard to the weight they place on such results. For instance, Maduka et al. (2017) in an empirical work, 'Globalization and Economic Growth: Evidence from Nigeria', had pointed out that following the integration of the Nigerian Economy into the global economy, its growth pattern has remained below expectation when compared with other countries of the world. Obaseki (2013) made a similar claim that Nigerian economy has become more open over the years but that its share of world trade has remained relatively low. Yet, Maduka et al. (2017), concluded that globalization has long-run significant positive impact on economic growth in Nigeria and that it was therefore safe to conclude Nigeria has actually benefitted from globalization through enhanced trade, investment and financial flows. Surprisingly, the above conclusions coexist with wide-spread low-capacity utilization, creeping unemployment, collapse of firms with consequent loss of jobs and an appalling poverty profile of citizens within the same economy and same time space (Aluko et al., 2004). This kind of manifest contradiction fuels stern rejection of wholesale globalization by the academic elite as panacea for the ills of the economies of developing countries. For instance, Aluko et al. (2004) have advocated that

"Globalization and all that accompanied it is not something to accept without question. It is something to be embraced with wisdom and reservations... and from all indications, globalization is associated with some risks and costs, and may have adverse implications for international economic stability. This notwithstanding, it also has its own potential benefits. But for a developing nation like Nigeria, the risks and costs associated with globalization seem to outweigh its potential benefits."

Given the above background we proceed by proposing the question as to whether domestic evidence in Nigeria supports the notion that globalization spurs growth of the local economy as canvassed by World Bank and the Britton wood Institutions? Obadan, 2001, in Adediran et al. (2015) provides an initial direction when he opined that globalization is an uneven process with unequal distribution of its benefits and losses. According to him this imbalance leads to polarization between the developed countries that gain, and the developing countries that lose out. A more depressing economic climate is further painted when they quipped that

"Nigeria is economically weak given its inadequate domestic economic ca- 
pacity and social infrastructure; mono-cultural dependency and unfavoura-

ble terms of trade and worrisome debt burden."

OzoekHome (2020), followed years later, with a more poignant account of the state of the nation, thus: "I am deeply sad that most of the well- known multinationals that once dotted the industrial and business landscapes of Nigeria, have either died, or folded up completely, or have since been downgraded; or they have relocated to small neighbouring countries. Some of them however exist only as mere museum relics and antiquities in the form of administrative office carcasses. Some of these olden days companies include the UAC, Leventis, Kingsway, UTC, Standard Banks, Barclays Bank, Lever Brothers (UNILIVER), PZ, John Holts, CFAO, Dunlop, Michelin, Volkswagen, Peugeot Automobile, Cadbury, NTC, May and Baker, RT Briscoe, etc. I am sad that no one can today show me the once famous Ajaokuta Steel Mills, the Itakpe Iron Ore, Delta Steel Company, Osogbo, Jos and Katsina Rolling Mills, the famous Northern Nigeria Kano Groundnut Pyramids, ... the Eastern Nigeria Oil Palm Produce, MidWestern Nigeria Rubber and Timber Produce, Okpella Cement Factory, Ughelli Glass Industries etc." The above harsh business environment is further complicated by rising inflation, high incidence of corruption and high cost of credit. All of these factors impact negatively on the global competiveness of Nigerian-made products. Again, there have been loud complaints raised by Nigerian business operators of the danger posed by unchecked globalization. For instance, Ogbonna (2020) had captured the anxiety of local entrepreneurs about possible loss of their businesses to venture capitalists when he opined that:

"Nigerian entrepreneurs under the auspices of Business Founders Coalition appealed to Nigerian President over what they considered hostile takeover bids of foreign private equity firms on their businesses...there are some who come into Nigeria literally to hijack the indigenous owned companies."

This may be regarded as a consensus opinion held by local business operators about the negative effect of unchecked globalization on the local economy and of the need to protect domestic industries. Essentially the group urges government to put in place policies that do not allow a foreign investor to have controlling rights in a Nigerian business. Against this backdrop therefore, we represent the questions as to whether globalization has helped the growth of Nigerian businesses or has it caused a decline in the growth of the economy? In what ways has the economy benefited from the phenomenon, if any? What policy path should the nation follow given available evidences? These are the issues the paper interrogates. The rest of the paper is as follows.

\section{Concepts and Theories of Globalization and the Intertwinement of Global Economy}

The 1990s have been christened decades of globalization as could easily be seen in the number of countries, including developing countries, which implemented 
economic reforms that are in sync with the goals of globalization (Gautam, 2014). The International Monetary Fund (IMF) and the World Bank's compulsory stabilization and Structural Adjustment Programme (SAP) template for countries accessing their funds helped immensely in stampeding countries towards market-oriented, export-led development strategies which has aided in integrating global economy (Gautam, 2014). First, what is globalization? Banerjee, 2012 in Gautam (2014) defines globalization as a phenomenon which integrates global economy with the objective of creating shared wealth through economic interdependence and cooperation, increasing economic relations between the developing and developed economies. Robertson (1992) in towing a historical path argued that globalization did not just happen. He identified five epochs in its trajectory, namely, 1) the germinal phase (1400-1750) of dissolution of Christendom and emergence of nationalism in Europe; 2) the incipient phase (1750-1875) of nation state and the initial phase of internationalism and universalism in Europe; 3) the takeoff phase (1875-1925) of conceptualization of the world as a single international society, global calendar, first world war, mass international migration and inclusion of non-Europeans in the international club of nation states; 4) the struggle for hegemony phase (1925-1969) of cold war, the emergence of League of Nations and the UN, and the emergence of third world, and 5) the uncertainty phase (1969-1992) of space exploration, recognition of global environmental problem and global mass media, via space technology. This historical calibration has merit on the following grounds. First, it shows the phenomenon is a child of antiquity that has metamorphosed through time under varied names to its current identity that now dominates public consciousness. Two, it helps to place in perspective, the time dimension when third world countries entered into global reckoning vis-à-vis other advanced economies. This second point bears repeating because quite often, exponents of globalization seem to gloss over this time lag that puts developing countries at a disadvantage when evaluating who gains and who loses from globalization and why. Arguments in favour of globalization seem to accept willy-nilly that all participants arrive at the arena equally prepared. This is far from reality. As may have been suggested, there does not yet exist, a definition of globalization which captures its many-sidedness. Therefore, there exists, a plethora of definitions. For instance, globalization is given as the multiplicity of linkages and interconnections that transcend the nation-state, McGrew, 1995 in Axford et al. (1997: pp. 491-495). This definition, it is argued, confirms the growing volume of goods, services, capital and people flowing across national boundaries. The point here is that the event has redefined the way things are done generally. It affects both individuals and businesses. The new concept of global consciousness has emerged to re-echo this fact. Business operators are often advised to think globally and manage locally. This means that they should be aware of the global forces acting on them. Hence, they should look at the world as a potential operating whole and should also adapt their strategies and company cultures accordingly. This is 
one sense of the phrase global consciousness. Furthermore, a more functional definition globalization exists. It could be rendered simply as the triumph of technology. However, Tandom was more poignant when he described globalization as the final conquest of the world by capital. In this third definition, three issues emerge, namely, the reality of an on-going economic battle between developed and developing societies; the emergence of two possible outcomes, the conqueror and the conquered or gainers and losers; the instrumentation of capital as the weapon of warfare. Hence, a society with vast endowment of capital lords it over the less-endowed.

Following from the above, it is discernible that globalization is capitalism in operation. Meanwhile, Marxist's theory of history casts capitalism as a system based upon the uneven development of colonial and metropolitan powers and on the systematic impoverishment of the third world (Axford et al., 1997: pp. 491-495). Axford et al. (1997: pp. 491-495) argues that in current world order, military imperialism has been replaced by forms of neo-imperialism carried on through the imbalance of trade between the First and the Third World and the power of transnational corporations with their roots in the First World to dictate the terms of world trade and investment. The First World is thus held as villain of underdevelopment of third world economies whereby the latter supplies mainly raw materials and labour to the core economies whereas the former produce and supply most high-value goods to the third world consumers, thus draining off capital which might otherwise be used to fund domestic investment and industrial modernization (Rodney, 1972: p. 208). Clearly, globalization generates such intense competitive pressures that could easily whittle down the value of local industries in developing economies. Kotler \& Armstrong (2005: p. 589) gave a poignant hint to the effects of the said competitive pressure along these lines,

"But today global competition is intensifying. Foreign firms are expanding aggressively into new international markets, and home markets are no longer as rich in opportunity. Few industries are now safe from foreign competition. ...domestic companies that never thought about foreign competitors suddenly find these competitors in their own backyard."

And it should be pointed out that the said competition takes place within context of weak technical and unfriendly macro-economic environments in the developing countries (Adediran et al., 2015). The implication of this, for trade related purposes, is succinctly captured by Aluko et al. (2004) when they averred that the products of Nigerian manufacturing sector, for instance, cannot compete with goods from advanced countries of the world most especially Europe and America. This is so because the combined effect of the hostile operating environment tended to make domestic products more expensive and inferior compared to the imported substitutes. It is therefore easy to tell who gains and who loses in the contest. In Nigeria, different sectors of the economy reflect the ugly dimensions of the outcomes of the competition. This is looked into later. 


\section{Globalization and Nigerian Economy: A Review of Literature}

The issue of the impact of globalization on African economies has been a subject of many debates and investigations. Therefore many theoretical and empirical works that interrogate the concept and show how they have affected some sectors of the African economy have accumulated. Bagachwa et al., 1995 and UNIDO, 1996 in Ayenagbo et al. (2012), for instance, claimed that trade liberalization has exacerbated the problems of domestic industries. They show how inexpensive commodities from technically advanced developing countries, particularly, South-East Asia have invaded the African markets. They further argued that where liberalization has fostered trade and created space for private sector and informal sector players, the field had been chiefly dominated by ethnic minorities, such as Asians in East Africa and Whites in South Africa or are all together taken over by their transnational corporations or their subsidiaries, whose interest is purely pecuniary and not the development of host local economies (Ayenagbo et al., 2012). In fact, they often encourage capital flights away from host economies back to their countries of origin. Hence, these firms merely act as conduit pipes that siphon wealth from host economies back to economies of origin. This further under-develops the host countries. Furthermore, the trade associations of Ghana, Nigeria and Zambia reported dumping and unfair competitions by these countries (Ayenagbo et al., 2012). It was further claimed that the excessive competitive pressures mounted by these firms have led to the closure of some local firms notably, soap, footwear and textiles firms (Ayenagbo et al., 2012). The textile industry in Nigeria provides a worst case scenario of the ugly side of globalization in an economy. For instance, the textile industry was held to contribute 48\% of GDP between 1972 and 1982 (Eke, 2007). This industry that once accounted for 37\% labour force has become moribund with $99 \%$ mills closed down (Eke, 2007). The account above largely agrees with the submissions of Maiwala \& Renne (2013). The duo traced the chequered history of the textile industry in Nigeria. According to them the first textile business in Nigeria was jointly owned by Northern Nigeria officials and British textile firm, David Whitehead and sons; they built the first biggest textile in Nigeria, Kaduna Textile Ltd (KTL), which took off in 1957. This opened the floodgate for others in the following decades such as the Arewa Textile, United Nigeria Textile Ltd (UNTL) and Norilex, among others. Growth in the sector continued unchecked up to 1970 s and through the oil boom years. According to them, by 2007, all three mills had ceased to exist.

The decline in fortune was created by both internal and external factors. Internal factors included frequent changes in political leaderships leading to shift in industrial policy and failure to maintain power infrastructure (Maiwala \& Renne, 2013). The external factor was traceable to the implementation of Structural Adjustment Programme (SAP) in 1986. SAP deregulated the currency and made imports of textile industry's spare parts and modern weaving equipment 
prohibitively expensive. Furthermore, changes in internal textile trade Agreements and liberalization of Nigeria-Chinese trade offer of 2010 undermined efforts to revitalize the local textile industry (Maiwala \& Renne, 2013). And again, the fact that Nigeria is a signatory to the liberalization policy of WTO led to the flooding of the local market with textile products from China, India, Indonesia, Australia, and Holland with more competitive brands (Ibid). The development has driven out local investors. And as at 2018, the textile import bill in Nigeria stood at 9.7M US dollars (Anyanwu, 2020). Today the textile industry is comatose with the attendant job losses.

These unintended outcomes happen mainly because the neoliberal agenda leaves little room for selective protection of domestic markets, especially by politically weak developing countries like Nigeria. This belies the hypocrisy of the most protagonists of globalization who built their economies behind high tariff walls. This point agrees largely with the view expressed by Kuttner, 2008, in Polivka \& Luo (2013) to the effect that most of today's dominant economies, including the United States of America, deployed selective trade policies to protect nascent industries and give them the time and financial resources needed to become competitive in the international economy. He therefore contended that developing country governments should also be permitted, and in fact encouraged, to use trade protection on selective, negotiated basis to strengthen their domestic industries, including agriculture. Again, Ayagi (1990) paints a more palpable, gloomier optic account of the real damage which globalization has inflicted on the economy. According to him, globalization has

"created parasitic economic relationships and has systematically pushed Nigeria into economic crises. This dependency culture created and entrenched, has thus made Nigeria a country, which does not produce but only consumes; so Nigeria imported everything and anything that anybody cared to advertise."

Even tooth picks! A visit to any of the shopping malls at the city centres in Nigeria will do as an eye-opener to the myriads of products of foreign origin that have taken over the markets.

The picture shown above serves as a precise and definitive account of the impact of globalization on selected parts of Nigerian economy. This represents a true picture captured from the perspectives of the grassroots. The said picture, in some ways (as shall be demonstrated soon), differs markedly from some of the accounts of empirical research findings that follow hereunder. And it is this dissonance between reality and what research findings showcase that agitates the curiosity of current authors.

As stated earlier, there are a number empirical works that spotlight how globalization has affected global economy. Those that focus on Nigerian economy cover the gamut, ranging from, banking and finance, agriculture, manufacturing sector, income, poverty or just its impact on the economy, generally (Maduka et al., 2017). As Maduka et al. (2017) reiterate, most of these previous studies pro- 
duced conflicting results. For instance, Feridun, et al. 2006, in Onwuka \& Eguavoen (2007), looked at the impact of globalization on economic growth in Nigeria. The time dimension covered was from 1986-2003. Johansen co-integration and error correction model (ECM) were the econometric tools employed for the study. The results indicate that trade openness has significant positive effect on economic growth in Nigeria. On the other hand, financial integration has negative but insignificant effect on economic growth in Nigeria. It needs to be specified here that proxies for globalization include, trade openness, foreign direct investments and financial integration (Maduka et al., 2017). Onwuka \& Eguavoen (2007) employed a descriptive analysis in evaluating the impact of globalization on the growth process of the Nigerian economy for the period spanning 1985-2001. The results revealed that Nigeria has not benefitted from globalization owing to her mono-cultural export, failure to attract increased foreign investment and large debt stock. In their study, Omolade et al. (2013) inquired into the link between globalization and economic development of Nigeria for the period, 1980-2011. The study used Johansen cointegration and Granger causality tests. It was found that trade openness relates negatively with economic development in Nigeria. It further observed that a unidirectional causality flows from economic development to globalization and not in reverse direction. It further showed that trade partners seem to be gaining more than the country especially the developed trading partners. Sede \& Izilein (2013) investigated the causal relation between economic growth and globalization in Nigeria. The study which employed Johansen cointrgation, Granger causality and variance decomposition tests, found that globalization does not Granger-cause economic growth in $\mathrm{Ni}$ geria. Okpokpo et al. (2014) looked at globalization as a tool for driving economic growth in Nigeria with emphasis on the non-oil export sector, namely, agriculture and manufacturing. The period covered in the study was from 1970 to 2011. ADF unit root test and OLS technique were employed and it was found that globalization has no significant impact on non-oil export and that globalization has not been a potent driver of the non-oil export in Nigeria. Again, Shuaib et al. (2015), studied the impact of globalization on Nigerian economy for the period, covering 1960-2010. The study employed the Johansen cointegration and error correction model. It was revealed that growth of external debt was inversely related to economic growth in Nigeria.

Furthermore, the deregulation of the financial system creates an avenue for funds to enter the local economy. As Oluwole (2014) has pointed out, globalization of the stock market, for instance, increases listings, raising of equity and debt capital and trading in domestic capital markets. This increases capital and fund flows across international borders, and thus creates access to funds needed for economic growth and development which otherwise could not have materialized. Along this line, Nwakanma \& Ibe (2014) examined the causal relationship between globalization and economic growth in Nigeria from 1981 to 2012. The results show a positive and significant relationship between financial integration, 
human resource development and trade openness. But it is also good to point out that these funds do not just move; funds owners exercise scrutiny of the safety status of funds' destination. In fact, Nwankwo (2020) clearly pointed out that funds are selfish; they go to where they are safe. The unstable macroeconomic environment, the perfidious judicial system, the corrupt political class, insurgency and herdsmen challenges complicate the Nigerian investment environment. On top of this, the rudimentary nature of the Nigerian capital market may not have helped the economy to benefit from external investors. This largely agrees with the thought expressed by Obaseki (2013) who submits that rapid inflow of capital has been stemmed largely as a result of the relatively underdeveloped financial market. There are other empirical works of note but the ones already given above suffice us. However, there are few sectors of the economy that might have had marginal benefits from globalization. These areas are highlighted in the next paragraph.

The first is Foreign Direct Investment (FDI). And as Onyimba et al. (2019) have argued, when fund flows come in the form of FDI, they often improve access to international best practices, in terms of managerial skill upgrade, marketing and technical know-how, skill acquisition and institutional deepening. These are intangible benefits that accrue to domestic recipient economies. The first level of instrumentation of FDI should be in the oil sector, the cash cow of the economy. Since the discovery of oil in commercial quantities in Nigeria in 1956, several oil prospecting companies have birthed on our shores. They include, Shell Development Corporation, Agip, Total, Texaco, ExxonMobi and Schlumberger. The operations of these foreign firms have not only impacted positively the revenue base of the country, they have aided in addressing critical needs such as employment generation, technical and manpower training of locals, sometimes offered in the form of scholarships to staff children and other Nigerians, prosecution of social responsibility projects such as building and equipping of health clinics for locals, building of bridges in rural areas, renovation of dilapidated public schools among others. Second, it is noteworthy to mention of the entry into Nigerian market space of some insurance and banking firms of foreign origin. Their presence, in Nigeria, has in some measures helped to address the unemployment challenge in the economy, besides their core intermediation role. This window was created by reform that allows financial firms of foreign origin to enter Nigeria. Third, and important, is the immense fund flows into Nigeria economy from the export of home-made videos by our artists which compete favourably with the Hollywood products on foreign soil. This revenue income is made possible through free movement granted to works of Arts. The fourth point relates to revenue inflow from Labour mobility across national boundaries including African continent and other continents of the world where Nigerian nationals reside and ply their trade. As Aluko et al. (2004) rightly posit, globalization involves widening and intensification of links between economies of the industrial and developing countries through trade, 
finance, investment, technology and migration. Labour mobility generates its own benefits for individuals and local economies. One way to assess the said benefit is to look at Diaspora Funds remittances. Only recently, the Nigerian Government officially accorded a formal recognition to the enormous potential that lay with diaspora residents. This was achieved through the formation of $\mathrm{Ni}$ gerian In Diaspora Commission (NIDO) (Oyebola, 2020). Nigerians in Diaspora are seen as agents of economic development achievable through skill and funds' transfer. It is estimated that about 15 million Nigerians are in the Diaspora (Oyebola, 2020). And a good number of these figure are qualified professionals, who ply their trades in Europe, America, and other parts of the world. This set of Nigerians have shown interest in the country's welfare which is reflected in home remittances and other humanitarian services. It is estimated that for the past three years, Nigerians in Diaspora have brought in over 25b US dollars, yearly as home remittances through official and non-official channels (Oyebola, 2020).

\section{Summary and Conclusion}

The paper has examined the concept of globalization in relation to Nigerian economy. Literature accounts showed various prospects which globalization can bequeath an economy if certain minimum macroeconomic and technological factors are guaranteed. Important areas where the economy has eked out some benefits were spotlighted. They include, Foreign Direct Investment, FDI, revenue inflows from works of arts exported to other countries and remittances from Diaspora residents. Clearly, especially from literature account and descriptive analysis, it may be correct to say that globalization has only marginally improved the lot of the economy as highlighted above. However, it is equally true that the phenomenon has undermined the growth of the local economy. A number of factors account for this. The first has to do with high quality products from technically advanced countries that compete with inferior but more expensive local variants on Nigerian soil. Consumers who want value for their money show preference for high quality and inexpensive foreign made products. This, in most cases, has forced local producers to wind up for lack of patronage. Related to the prior, is the long entrenched penchant of Nigerians for foreign made products. In the psyche of local consumers is the subtle association of imported products with high quality feature while local counterparts are seen as inferior. This hurts local manufacturers and as such cannot stand competition from imported products. Local manufacturers need therefore need an administrative policy shield in order to thrive. Again, the fact that our economy is almost exclusively propped on a mono-product, oil crude, exposes it to external shocks in the international oil markets. This makes revenue receipts from oil uncertain and hence constrains development programmes. The last point has to do with the policy environment in Nigeria. The Nigerian policy environment enjoys exclusive deficits in most of the major factors that count in global market place. An 
objective categorization of the country would be an economic space characterized and burdened with conditions of unstable macroeconomic management, infrastructural deficits, weak technical base, inefficient financial system, corrupt and untoward political class, abysmal industrial capacity utilization, epileptic, inefficient power supply and a high rate of youth unemployment. Add to the mix, increasing security risks from insurgency, Boko Haram, herders-farmers' conflict and armed banditry and you have a dire investment environment that not only stunt growth but erodes investors' confidence.

The paper therefore concludes that although Nigeria may have benefitted from the opportunities created by globalization as has been amply stated above, the country may have paid so dearly in the form of retrenchment of workers in companies bleeding from under capacity utilization, deficient consumer demand, unemployment occasioned by firms that have had to fold up because consumers now prefer cheaper and better brands offered by foreign firms operating in our backyard. Given the scenario above, the policy path is to entrench strategies that encourage diversification of the productive base of the economy via private sector-led initiative while putting in place policies that shield local entrepreneurs from unhealthy competition from imported and cheaper products.

\section{Conflicts of Interest}

The authors declare no conflicts of interest regarding the publication of this paper.

\section{References}

Adediran, O. A., Adeyemo, K. S., \& Alalade, S. (2015). Globalization, Capital Market and Economic Development in Nigeria. Journal of Governance and Regulation, 4, 57-62. https://doi.org/10.22495/jgr v4 i4 p6

Aluko, M. A. O., Akilola, G. O., \& Fatokun, S. (2004). Globalization and the Manufacturing Sector: A Study of the Selected Textile Firms in Nigeria. Journal of Social Science, 9, 119-130. https://doi.org/10.1080/09718923.2004.11892440

Anyanwu, C. (2020). Bt Cotton Critical to Revival of Textile Industry, Job Creation-Experts. Daily Sun, 17, 22.

Axford, B., Browning, G. K., Huggins, R., Rosamond, B., Turner, J., \& Grant, A. (1997). Politics: An Introduction. London: Routlege.

Ayagi, I. (1990). The Trapped Economy: Nigeria, a Non-Ideological Strategy for Self-Reliance. Heinemann Educational Books (Nigeria Ltd.), Ibadan.

Ayenagbo, K., Rongcheng, W., Wang, W. J., Nguhi, S., Kimatu, J. N., \& Patrick, J. M. (2012). The Impact of Globalization on African Countries' Economic Development. Journal of Business Management, 6, 11057-11076. https://doi.org/10.5897/AJBM12.828

Eke, E. (2007). Death of Textile Sector: High Cost to the Economy. The Guardian, 25, 28-29.

Gautam, N. (2014). How Much Is South Asia Globalized?

https://.researchgate.net/publication/342719329

Ianchovichina, E., \& Martin, W. (2004). Impacts of China's Accession to the World Trade Organisation. The World Bank Economic Review, 18, 1-27. 
https://doi.org/10.1093/wber/lhh030

Kotler, P., \& Armstrong, G. (2005). Principles of Marketing (11th ed.). Upper Saddle River, NJ: Pearson Prentice Hall.

Lawal, O. A. (1982). A Level Economics of West Africa. Ibadan: Heinemann Educational Books (Nig) Ltd.

Maduka, A. C., Madichie, C. V., \& Eze, E. (2017). Globalization and Economic Growth: Evidence from Nigeria. International Journal of Social Science and Economic Research, 2, 4177-4191.

Maiwala, S., \& Renne, E. (2013). The Kaduna Textile Industry and the Decline of Textile Manufacturing in Northern Nigeria, 1955-2010. The Journal of Textile History, 44, 171-196. https://doi.org/10.1179/0040496913Z.00000000027

Nwakanma, P. C., \& Ibe, R. C. (2014). Globalization and Economic Growth: An Econometric Dimension, Drawing Evidence from Nigeria. International Review of Management and Business Research, 3, 771-778.

Nwankwo, S. (2020). COVID-19 Pandemic: Sustainability of Livelihoods and Businesses in Developing Economies (Professor Sunny Nwankwo's Conversation at the Recent Colloquium Hosted by Unizik Businness School).

Obadan, M. I. (1993). Overview of Nigeria’s Exchange Rate Policy Management since the Structural Adjustment Programme. CBN Economic and Financial Review, 31, 367-382.

Obaseki, P. J. (2013). Globalization and Nigerian Economy. Central Bank of Nigeria Economic and Financial Review, 38, 17-33.

Ogbonna, A. (2020). Nigerian Business Founders' Coalition Send SOS to Buhari. Daily Sun, $17,2$.

Okpokpo, G. U., Ifelunini, I. A., \& Osuyali, F. (2014). Is Globalisation a Potent Driver of Econonomic Growth? Investigating the Nigerian Non-Oil Export. Asian Economic and Financial Review, 4, 781-792.

Oluwole, F. O. (2014). Globalization and the Stock Market Growth in Nigeria. European Scientific Journal, 10, 317-332.

Omolade, A., Morakinyo, A., \& Ifeacho, C. (2013). Globalization and Economic Development in Nigeria. Journal of Research in Humanities and Social Science, 1, 6-14.

Onwuka, E. C., \& Eguavoen, A. (2007). Globalization and Economic Development: The Nigerian Experience. Journal of Social Science, 14, 45-51.

https://doi.org/10.1080/09718923.2007.11978398

Onyimba, R. C., Nwokediuko, J. N., \& Ewa, B. E. (2019). Effect of Globalization on Growth and Development of Nigerian Capital Market. International Academy Journal of Management, Marketing and Entrepreneurial Studies, 7, 21-32.

Oyebola, K. (2020). Mobilizing Diaspora Nigerians for National Development. The Guardian, 37, 10-11.

OzoekHome, M. (2020) Me Celebrate Nigeria at 60? Sorry, No!!! Daily Sun 17 (4553):31. https://www.vanguardngr.com/2020/09/me-celebrate-nigeria-at-60-sorry-no/

Polivka, L., \& Luo, B. (2013). The Future of Retirement Security around the Globe. Journal of the American Society on Aging, 37, 40-45.

Robertson, R. (1992). Globalization: Social Theory and Global Culture. London: Sage Publications.

Rodney, W. (1972). How Europe Underdeveloped Africa (2009 ed.). Abuja: Panaf Publishing, Inc.

Sede, I. P., \& Izilein, E. I. (2013). Economic Growth and Globalization in Nigeria: A Cau- 
sality Analysis. Asian-African Journal of Economics and Econometrics, 13, 145-159.

Shuaib, M., Ekeria, O. A., \& Ogedemgbe, A. F. (2015). The Impact of Globalization on the Growth of Nigerian Economy from 1960-2010: Error Correction Model Analysis. British Journal of Economics, Management and Trade, 7, 63-73. https://doi.org/10.9734/BJEMT/2015/14698

Williamson, J. G. (1997). Globalisation and Inequality, Past and Present. The World Bank Research Observer, 12, 117-135. https://doi.org/10.1093/wbro/12.2.117 